\title{
Cannibalism \& Politics: the English Renaissance Revisited
}

\author{
Dr Lauren Working
}

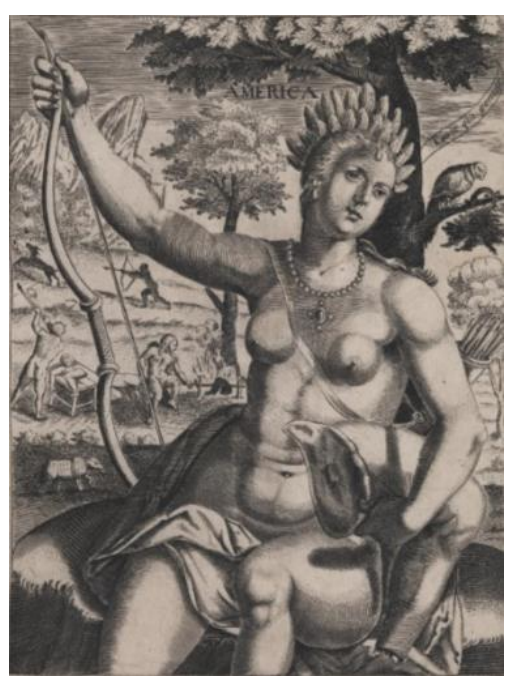

'America' engraving from 'The Four Continents', c. 1630s, British Museum, BM 1870, 0514.1176. CC BY-NC-SA 4.0.
The British Museum's Prints and Drawings collection, located several floors above the Royal Anthropological Institute Library, contains an engraving from the 1630s depicting America personified as a woman, adorned with pearls and feathers. In her hand, she holds a human leg, torn from its body in an ostensible act of cannibalism, while background figures continue their rituals of consumption.

Associations between Native Americans, violence, and bloodlust became regular features in European colonial discourse from 1492. References to torn and dismembered body parts ravaged by cannibalism appeared in maps, political discourses, sermons, and on the frontispieces of printed books across Europe in the sixteenth and seventeenth centuries. Even as members of the elite in England filled cabinets and private chambers with luminescent paintings that celebrated the beauty of the human form, composed by artists who learned from anatomical observation, they simultaneously encountered descriptions and representations of indigenous Americans committing acts of extreme violence.

In The Man-Eating Myth (1979), the anthropologist William Arens critically assessed purported instances of cannibalism in different parts of the globe and argued that most European accounts that documented man-eating could be seen as misrepresentations, intentional or no, of indigenous beliefs. As Arens pointed out, accusations of 'savage' rituals recounted by colonists could easily serve to justify imperialism. From Columbus onwards, rumours of cannibalism written by Europeans seemed to provide convenient 'proof of indigenous peoples' seeming inability to govern themselves. It has become the norm for historians to argue that representation matters as much as, if not more than, the anthropological realities of cannibalism: examining what Europeans were willing, or purported, to believe indicates a great deal about European societies, if not American ones.

While cannibalism as 'othering' has been extensively studied in postcolonial studies, it seems an insufficient way to explain the full breadth of early modern cross-cultural exchange. Although their conceptions of Native American societies were deeply biased and incomplete, the pervasiveness of the cannibal metaphor in English political discourse gained its salience from actual encounter and from a complicated interaction between representations and lived experience. Ideas about indigenous violence operated alongside a fascination for Native artefacts and commodities, from featherwork to tobacco. This article explores how anthropological approaches to Anglo-Native American exchanges in the Renaissance - thinking through and beyond terms like 'cannibal' that inherently involved an attention to indigenous America - can shed light on the different facets of encounter in ways that better emphasize its varied, sometimes unexpected influences on English heritage. This has implications for how museums curate and form narratives around Native American objects in national collections, and opens up possibilities for new approaches to historical research that can provide a deeper assessment of colonial legacies and the possibilities of reconciliation.

\section{Anthony Knivet and Yellow Sun}

The cultural and literary studies about cannibalism that emerged in the late twentieth century developed partly in response to Arens' questions over the validity of European accounts as reliable testimonies. His arguments about how accusations of cannibalism served to legitimize expansion and subsume indigenous peoples shaped the work of historians and literary scholars who subsequently re-examined colonial encounters in ways that emphasized representation and European aspirations to colonial dominance 
(Arens 1979; Greenblatt 1991; Lestringant 1997; Hulme 1986; Whitehead 2000; Avramescu 2009). Arens rightly questioned narratives of 'savage' Native Americans juxtaposed against 'civil' or 'enlightened' Europeans, but there is some risk in automatically dismissing all descriptions of cannibalism as false. This frees historians from having to engage seriously with Native American anthropology and alternate forms of meaning-making and knowledge-transmission. An unfortunate if mostly unintentional consequence of arguing that the historical reality of cannibalism is unimportant is that the values and lived conditions of Native groups are not seen as essential components of the narrative of 'English' or 'European' history. This continues to marginalize non-white populations by dismissing the complexities and influence of their particular practices, beliefs, and lifeways. In the decades since Arens' study, detailed fieldwork by anthropologists and archaeologists have demonstrated that the taking and consuming of human body parts occurred in specific contexts for multiple reasons, from avenging deaths to assisting in spiritual ceremonies or commemorating the dead (Chacon \& Dye 2007; Forsyth 1983; Sanday 1986; Fausto 2012; Conklin 2001). Early modern historical sources, though they must be placed within their proper contexts and treated with appropriate degrees of scepticism, have at times corroborated the oral histories and narratives told by indigenous peoples.

The Englishman Anthony Knivet serves as a case study. Knivet spent most of the 1590s in Brazil, leaving an extensive account of the indigenous groups he encountered in Purchas his Pilgrims, a

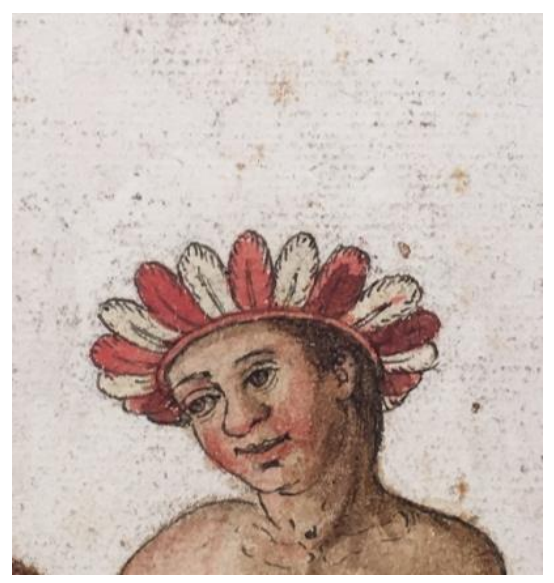

Detail from John White's watercolours [after woodcuts in Jean de Léry's account of the Tupinambá], c. 1580s, British Museum, SL, 5270.10. CC BY-NCSA 4.0. large compendia of travel writing edited by the Protestant churchman Samuel Purchas in 1625. Knivet recorded differences between subgroups of the Tupi-Guarani, Tapuia, and Carib. He spent years among the Tamoio (Tupi) and noted extensive differences between the customs and practices of numerous Brazilian groups. It would be easy to assume Knivet's continual references to 'the cannibals' operated solely to dismiss Brazilian socio-cosmic systems, as Arens might have maintained, but Knivet's difficult, rambling account contained begrudging acknowledgments about the practical and inventive ways in which indigenous peoples thrived in their environments. For every flamboyant story about fighting snakes by torchlight or narrow escapes from the Catholic Inquisition, Knivet's text included details about diets, village structures, and spiritual beliefs. Among the Purí, Knivet met Quiarasipsinca, a 'great man in his Countrie', translating his name as 'yellow Sunne' and declaring that '[n] ever man found truer friendship of any than I did of him' (Purchas 1625: 1210). Knivet made distinctions between those who ate human beings and those who did not 'glorie so much to eate mans flesh' (Purchas 1625: 1228).

Those Knivet described as prone to acts of cannibalism were mostly the coastal Tupi, groups whose descendants have acknowledged the historic importance of cannibalism in their identities.

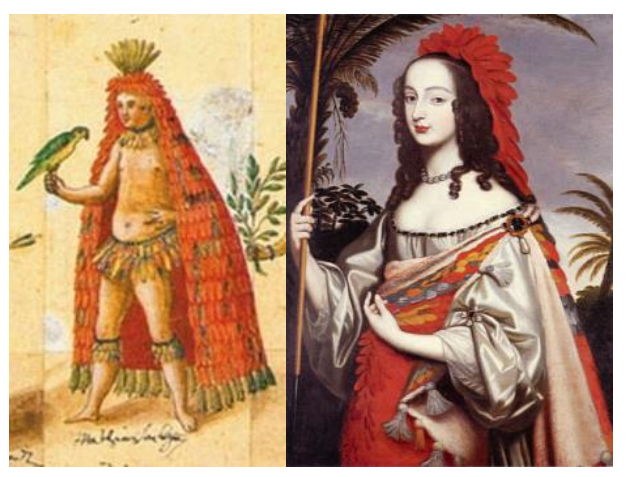

German depiction of a Tupinambá man from Der Aufzug der 'Königin Amerika', 1599; Sophia of the Palatinate, granddaughter of James I, in a c. 1644 portrait painted by her sister, Louise. Both (C) Wikicommons.
Anthropologists have found that vengeance, with and without cannibalism, drove much of Tupinambá warfare in both the pre and post-contact era, just as enmity held a central place among other Brazilian groups (Salomon \& Shwartz 1999; de Sá 2015; Fausto 2012). Tupis 'evoked a terrible cycle of vendettas' in carefully-prescribed rituals and ceremonies that were integral to their social cohesion (Hemming 1978: 30-1). Automatically dismissing all descriptions of cannibalism risks stripping agency from those whom scholars have pointedly tried to restore agency to.

Knivet's account demands a critical eye. Pressured to produce a Protestant, anti-Iberian narrative for his English readers, and writing some years after his time in Brazil, multiple imperatives informed the finished product. Nonetheless, Knivet's descriptions of the coastal Carijós and Tupinambá, and the Tapuia/Jê-speaking Tapuia, although imperfect, at the 
very least encourage a reconsideration of English intervention and experience in the Americas. Knivet had practical reasons for being as accurate as possible: his Portuguese master had employed him to trade for slaves, bringing indigenous men and women to work on Portuguese sugar mills for a rapidly developing industry that fed into European tastes for luxury goods. Accounts like Knivet's served as blueprints to encourage further colonial intervention and reveal English involvement in colonial projects that are often dismissed as belonging solely the domain of Continental, Catholic empires of the time.

A source like Knivet's is further useful for thinking about how to teach, or display, indigenous material in university curricula and English museums. On one hand, the account encourages approaches to early modern travel that emphasize indigenous spaces, where greater weight can be placed on Knivet's position of vulnerability and the way in which he depended on indigenous transport and food to survive. At the same time, such narratives require a deeper engagement with the role that the English played in intelligence-gathering and imperial devastation, including the enslavement of Native Americans, some of whom ended up as sailors in English ships or as servants in the households of London politicians and merchants. To dismiss Knivet's use of 'cannibal' purely as an indicator of European power over Native peoples is to prevent more difficult, but more fruitful, approaches and displays about how societies and cultures

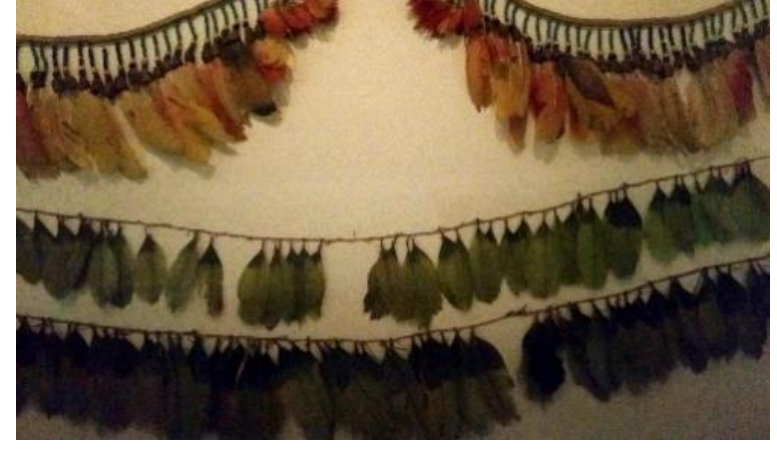

Strings of South American feathers on display at the World Museum in Liverpool. Image is author's. encountered and influenced each other.

Artefacts become important mediators in these alternate approaches to colonial encounters. Examining extant examples of indigenous material culture demonstrates the sophistication of the Tupi societies that Knivet encountered behind the blanketing labels that appeared in his narrative. In particular, featherwork exposes the tensions that were often at play in English attempts to both subordinate and exploit South American societies. While the English frequently condemned 'cannibal' violence, they also spoke highly of the lustre of parrot feather adornments, creating a disjunction between the seeming chaos of indigenous violence on one hand, and Native artistry and techniques of making on the other. Featherwork can present a more nuanced view of how Native American individuals in the sixteenth and seventeenth centuries constructed meaning and preserved their belief systems while inviting questions over how such precious objects found their ways to English collections over the centuries. Rather than displaying featherwork in an isolated case, which gives visitors little sense of why such objects are there in the first place, these artefacts can be used to raise attention to the potency of featherwork in Native spiritual ceremonies while relating to changing tastes and trends within Europe as a result of expansion.

\section{'Tupi or not Tupi': Confronting Imperial Legacies}

In 1928, the poet and member of the Brazilian modernist movement, Oswald de Andrade, published his 'Cannibalist Manifesto'. One line appears in English: 'Tupi or not Tupi, that is the question' (de Andrade \& L. Bary 1991: 38). Playing on Hamlet's soliloquy, the phrase isn't just a sonorous line of philosophical query, or a clever way to reverse incorporation. It draws attention, however incidentally, to the fact that the world of Shakespeare was enmeshed in that of colonial intervention. The French essayist Michel de Montaigne's musings on the Tupinambá in 'Of Cannibals', or the presence of South American featherwork in the Spanish and Italian courts, have been explored in far more detail than Native Americans in English Renaissance culture. Yet English ethnographic curiosity - subjecting Native Americans to observation and display while compelled to articulate their own identity in relation to indigenous peoples - was evident from the earliest colonial efforts. Shakespeare's character of Caliban in The Tempest formed an anagram of 'cannibal'. The play's shipwrecked jester, Trinculo, proclaimed that Londoners 'will not give a doit to relieve a lame beggar, [but] they will lay out ten to see a dead Indian' (Act 2, Scene 2). 


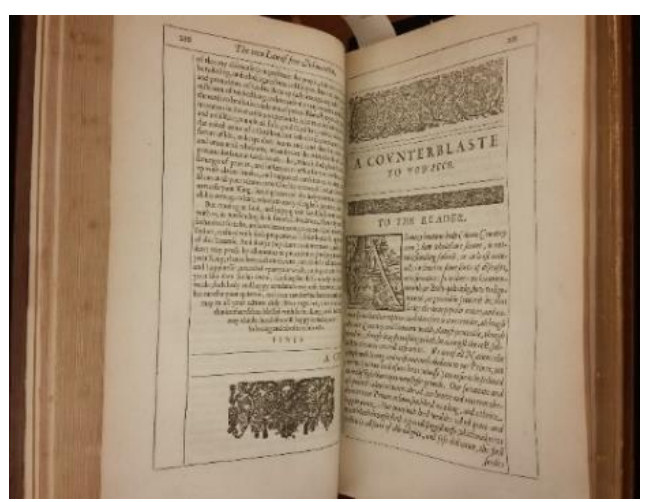

The Huntington Library's edition of James I's 'Counterblaste to tobacco', included in the king's Works (1616). Image is author's.

The term 'Indian' was a fluid one in early modern England, where the East and West Indies were often used as discursive spaces for fantastical imaginings that involved both sumptuousness and rawness. Yet Shakespeare's line also hints at a series of interconnected but distinct attitudes to expansion and encounter behind the stereotypes, one in which the search for 'India' and the wealth of Eastern empires necessitated colonial intervention and the establishment of American plantations. Displaying 'Indians', and placing characters like Caliban on the stage, pandered to Londoners' fascination with the unknown while inviting viewers to draw judgements between themselves and those 'savages' or 'cannibals' who would ostensibly benefit from the civilizing initiatives of the English. At the same time, a rich realm of encounters are left to be explored and situated within these better-known literary examples. The mathematician Thomas Hariot, a protégée of Ralegh's, compiled an Algonquian dictionary in a house on the Strand in London, assisted by several North American interpreters. Words like pecan, squash, burricane, and hammock appeared in translations and travel texts written and collected by merchants and joint stock company agents in London. These words spilled out of manuscripts and into pamphlets and broadside ballads that were read and recited by a large demographic of English men and women. Indexes, languages lists, dictionaries and translations that brought Native words and associations into English discourse can highlight the two-way influence of exchange and contribute to conversations around the United Nations' 2019 theme, the Year of Indigenous Languages.

Using indigenous material culture to animate different facets of encounter make museums important sites for re-thinking English imperial history. The call to 'decolonize' museums in initiatives such as the 'Museums Are Not Neutral' or 'alternative' art tours are attempts to bring the darker legacies of slavery and global exploitation out of obscurity, and to prompt visitors to think more critically about the costs and consequences of object-acquisition and national myths. What might greater attention to the interplay between colonial intervention and the effect of indigeneity on domestic culture look like? Small changes can create profoundly different perspectives on objects and their histories. At the 2018 'Slaves of Fashion' exhibition at the Walker Gallery in Liverpool, curators chose to place a porcelain teacup, that shorthand for refined eighteenth-century sensibility, next to slave chains.

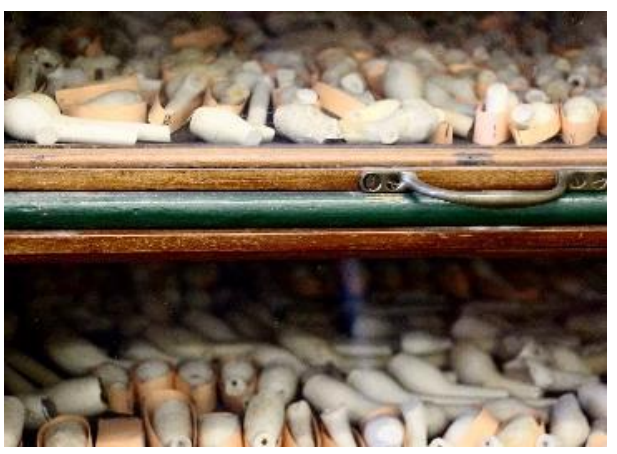

A small selection of the National Pipe Archive's seventeenth-century tobacco pipes, held at the University of Liverpool. Image is author's. Placing indigenous featherwork or terra cotta tobacco pipes next to a portrait of Walter Ralegh, who travelled to Guiana around the same time Knivet crossed Brazil, might begin to show the cross-over between English and Native histories. Displaying Algonquian, Nahuatl, or Carib dictionaries and loanwords alongside Latin phrases when discussing humanist culture and Renaissance textual transmission could do the same. Such displays would resist the tendency to keep the colonial in isolation from the domestic or to present colonization as a remote elsewhere. 


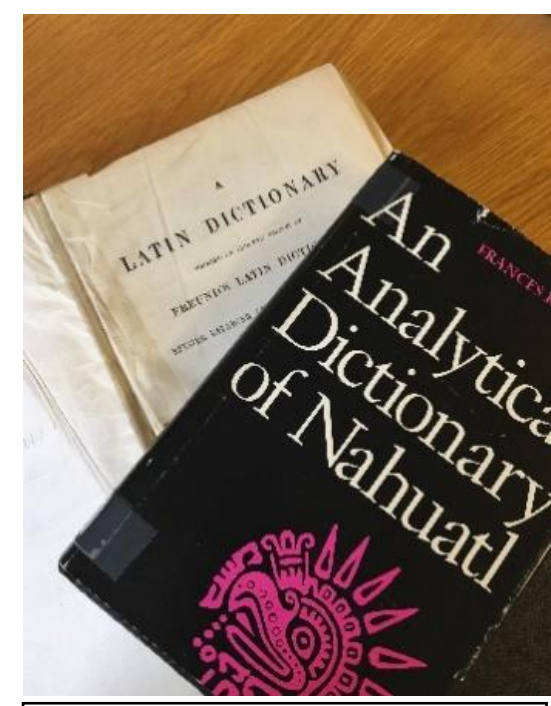

Languages of the early modern. A Latin dictionary next to a dictionary of Nahuatl, from the stacks at the RAI. Image is the author's.
A willingness to revisit Renaissance ethnographic writing and to enter into dialogue with contemporary Native American groups can address ongoing concerns by activists and NGOs who continue to petition for indigenous rights. Knivet's details about Tupi anthropology can be important in acknowledging the existence and freedoms of indigenous groups at a time when Brazil's president, Jair Bolsonaro, has professed blatant hostility to their rights in the Amazon, and where gas pipelines and drilling wells have extended to the lands of uncontacted groups like the Nanti in Peru (The Guardian 2018). Bolsonaro's statements about Native Americans as little more than obstacles to agribusiness, their land containing untapped opportunities for wealth, sound remarkably like the Elizabethan promotional tracts produced in sixteenth-century printers' shops just a few miles from where the RAI Library now stands.

Searching for indigenous voices and agency in the long histories of encounter can also speak to contemporary indigenous appeals for reconciliation. This is not just a problem for the United States or Canada. Healing the wounds of colonialism can only happen after institutions better confront the imperial past and the devastating legacies that the English helped first put in motion. As the

Kwakwaka'wakw artist and activist Sierra Tasi Baker put it during her visit to London: 'the more [that] researchers start shifting to[wards] realizing that they're helping [to] change the narrative, and shift the narrative, [the more] that they are agents of reconciliation...research is a form of healing' (Beyond the Spectacle 2019). Working across disciplinary boundaries, using textual and material sources together and consulting and collaborating with indigenous groups can bring the premodern and the modern in dialogue with each other in a significant way, prompting a reconsideration of the value of historical objects for the present. While finding the best means of querying and redisplaying objects is an ongoing process, dependent on a range of factors including the type of object, their provenance, and institutional funding, seeking collaboration with indigenous peoples remains essential.

Integrating the material archive and Native voices into the seemingly well-known histories of political thought and cultural history demonstrate how the English exposure to indigeneity informed their ways of seeing and constructing themselves. This involves understanding the function of certain terms, like 'cannibal', that the English used to explore concepts of violence, social order, and religious belief. But it also means engaging seriously with Native American anthropology and attempting to recreate the experiences and exchanges of those who operated beyond those terms. There is scope for revisiting the Renaissance canon in ways that can create new displays, museum labels, collaborations, and responses that prompt museum visitors and students to understand their historic connection with indigenous groups. From the American dyes, pearls, and pigments in portraits of Elizabethan explorers, to John Milton's mention of feather belts in Paradise Lost, there are abundant opportunities to weave indigenous beliefs and lives into the histories of English consumption and display, civility, state formation and literature. 'I will be', Matoaka/Pocahontas reportedly told John Smith in London shortly before her death in 1617, 'for ever and ever your Countryman' (Smith 1624: 123).

Lauren Working is a historian on the European Research Council-funded TIDE project (Travel, Transculturality, and Identity in England, 1550 - 1700) at the University of Liverpool. She was 2018 Royal Anthropological Institute Library fellow. 
Bibliography

de Andrade, O. and L. Bary 1991. 'Cannibalist Manifesto'. Latin American Literary Review, 19: 38-47.

Arens, W. 1979. The Man-Eating Myth: Anthropology and Anthropophagy. New York: Oxford University Press.

Avramescu, C. 2009. An Intellectual History of Camnibalism, tr. Alistair Ian Blyth. Princeton: Princeton University Press.

Chacon, R J. and D.H. Dye (eds.) 2007. The Taking and Displaying of Human Body Parts as Trophies by Amerindians. New York: Springer.

Conklin, B.A. 2001. Consuming Grief: Compassionate Cannibalism in an Amazonian Society. Austin: University of Texas Press.

Davy, J. Research is a Form of Healing: Beyond the Spectacle interview with Sierra Tasi Baker, 11 January 2019. Available: <https://blogs.kent.ac.uk/bts/2019/01/11/research-is-a-form-of-healing> Accessed: 16 January 2019.

Fausto, C. 2012. Warfare and Shamanism in Amazonia. Cambridge: Cambridge University Press.

Forsyth, D.W. 1983. 'Beginnings of Brazilian Anthropology: Jesuits and Tupinambá Indians'. Journal of Anthropological Research, 39: 147-78.

Greenblatt, S. 1991. Marvellous Possessions: The Wonder of the New World. Chicago: University of Chicago Press.

Hemming, J. 1978. Red Gold: The Conquest of the Brazilian Indians. Cambridge: Harvard University Press.

Hulme, P. 1986. Colonial Encounters: Europe and the Native Caribbean, 1492 - 1797. London: Methuen.

Knivet, A. 'The admirable adventures and strange fortunes of Master Antonie Knivet' (1202-32), in Purchas, S. 1625. Purchas his pilgrimes. London.

Lestringant, F. 1997. Cannibals: The Discovery and Representation of the Cannibal from Columbus to Jules Verne, tr. Rosemary Morris. Cambridge: Polity.

Monteiro, John M. 'The Crises and Transformations of Invaded Societies: Coastal Brazil in the Sixteenth Century', 973-1024 (986-9), in Salomon, Frank and Stuart B. Schwartz (eds.) 1999. The Cambridge History of the Native Peoples of the Americas: Vol. 3, South America. Cambridge: Cambridge University Press.

de Sá, V.J.L (ed.) 2015. The Admirable Adventures and Strange Fortunes of Master Anthony Knivet: An English Pirate in Sixteenth-Century Brazil. Cambridge. Cambridge University Press.

Sanday, P.R. 1986. Divine Hunger: Cannibalism as a Cultural System. Cambridge: Cambridge University Press.

Smith, J. 1624. The generall historie of Virginia. London.

Watson, F. Bolsonaro's election is catastrophic news for Brazil's indigenous tribes. The Guardian, 31 October 2018. Available: <https://www.theguardian.com/commentisfree/2018/oct/31/jair-bolsonarobrazil-indigenous-tribes-mining-logging> Accessed: 28 January 2019.

Whitehead, N. 2000. 'Hans Staden and the Cultural Politics of Cannibalism'. The Hispanic American Historical Review, 80: 721-51. 